\title{
Analysis of the Effectiveness of the Occupational Safety and Health Policy in three Industries in Trinidad and Tobago
}

\author{
Mark Allen, Ph.D. \\ Department of Chemistry \\ University of the West Indies \\ Mona Campus, Jamaica \\ Contact co-author - Robert Dibie, Ph.D. \\ Department of Public Administration and Health Management \\ School of Business, Indiana University Kokomo \\ E-mail: rdibie@yahoo.com
}

Received: Aug. 22, 2019 Accepted: Sep. 16, 2019 Online published: Oct. 10, 2019

doi:10.5296/jpag.v9i4.15606 URL: https://doi.org/10.5296/jpag.v9i4.15606

\begin{abstract}
This paper investigates the effectiveness of the occupational safety and health (OSH) policy in the construction, manufacturing, and petrochemical industries in Trinidad and Tobago since it was enacted in 2006 up until 2017. Existing literature copiously reports on the degraded levels of occupational safety and health (OSH) in developing countries and recommends the adoption of integrated approaches to workers' health protection. Although this assertion may be correct for some Caribbean countries it might not be true for all. This paper argues that inadequate enforcement of the OSH policy, oversight, and accountability strongly suggests that the Government of Trinidad and Tobago is not serious about its OSH policy. The data for this paper were derived through interviews and questionnaire research instruments. The result of the research found that there has been limited gains and few positive policy outcomes. This is because the OSH Agency does not pursue a coordinated policy implementation initiative, and this shortcoming has contributed negatively to the underlying and persistent absence of employers' commitment to complying with the national OSH policy. It is prudent and urgent that a re-energized and creative approach to policy
\end{abstract}


implementation be adopted, and that essential tools, resources, strategic direction and executive oversight are provided to ensure sustenance and success of this important change-management process.

Keywords: public policy, occupational safety and health, environmental health, impact analysis, sustainable development, social protection, worker representation, social and economic impact

\section{Introduction}

The Republic of Trinidad and Tobago is the most industrialized nation among the small island states of the Caribbean (World Bank Group 2019; Carneiro. et al 2014). It has a large and diverse industrial sector and there are over twenty-nine thousand small, medium and large industrial establishments, many of which are located on the several industrial estates across the country (World Bank Group 2019; Suarez \& Elias 2006). Several occupational safety and health risk predicaments are visible in Trinidad and Tobago, and a large percentage of the national workforce are employed in hazardous occupations (Government of Trinidad and Tobago 2013, Allen \& Dibie 2016).

The government of Trinidad and Tobago enacted modern and comprehensive occupational safety and health (OSH) policy in January 2004. The OSH Act of 2004 (as amended 2006) replaced the Factories Ordinance of 1946, which was considered to be narrow in scope, outdated and inappropriate to deal with the expanding industrial sectors in the country (Government of Trinidad and Tobago, 2010). Additionally, most occupations and workplaces fell far outside the ambit of its legal framework. Before 2004, workers in Trinidad and Tobago suffered from various occupational diseases caused by exposure to general conditions and hazards encountered in the work environment (Dibie, 2014). Recognizing this, the various stakeholders turned their attention to issues related to the "quality of work and the capacity for workers to be more productive at the workplace in the country. The OSH policy challenges include job security, job satisfaction, lack of enough inspectors, and pragmatic occupational safety and health initiatives as well as resources. The heightened construction, manufacturing, petrochemical and agricultural industrial sectors' workers awareness of environmental health issues caused them and their unions to adopt a more pro-active approach to potential hazards in the workplace (Dibie 2013; Allen \& Dibie 2016).

The new OSH Act of 2006 resulted in the establishment of two agencies: (a), the Occupational Safety and Health Agency; and (2) the Occupational Safety and Health Authority (Government of Trinidad and Tobago, 2010). The OSH agency is the enforcing body whereas the OSH authority is primarily concerned with policy formulation, development, incorporation and adoption of regulations, standards and codes of practice (Government of Trinidad and Tobago, 2010). The goal of the OSH policy is to ensure the safety, health and welfare of persons at work and to protect others against risks to safety or health in connection with the activities of persons at work (Government of Trinidad and Tobago, 2010). A key goal of the policy is that organizations have the duty to ensure a good health, safety and welfare at work of all his/her employees (Friis 2019; Maxwell 2014). On the other hand, the OSH policy aligns with the general consensus that all workers in the 
respective countries have a fundamental right to a healthy and safe working environment (Dibie 2013; Friis 2019; Maxwell 2014; Moreau \& Neis, 2009).

An in-depth evaluation has not been undertaken to determine the impact of the provisions of occupational health and safety policies within Caribbean countries (Allen \& Dibie 2016). In the main time, their policy context would have included the ILO's Regional Safe-work Agenda; the PAHO's Regional Workers' Health Plan and Workers' Health Strategic Orientations; and the CARICOM's Caribbean Cooperation in Health $(\mathrm{CCH})$ strategies and Regional Health Agenda (Friis 2019; Maxwell 2014).

Several studies have drawn their finding and conclusion from single data source such as the health industry in Trinidad and Tobago rather than research the construction, manufacturing, health, agriculture, and petroleum industries (Lavicoli et al, 2011; Dahle et al 2010; Moreau $\&$ Neis 2009; Dibie 2013). The complexity of the issues underlying workers vulnerability to occupational injuries clearly indicates the need to develop a holistic approach that combines several industrial data sources. Without such data resource in the country it could be difficult to develop integrative models that could provide information about operations conducted in the major industrial sectors in Trinidad and Tobago.

Since the Trinidad and Tobago OSH policy was enacted in 2004 and amended in 2006, no research has been conducted on psychosocial risk factors and issues such as work-related stress, harassment, bullying and violence at work in the country. These factors are increasingly been acknowledged as potential threat to workers' safety and health as well as productivity. In this context, this paper will explore the level of knowledge of the Trinidad and Tobago OSH policy initiatives as well as related differences in perspectives and approach to psychosocial risk management in the country.

The petrochemical industry in Trinidad and Tobago has been identified as a major pollution source (World Bank Group 2019; Government of Trinidad and Tobago 2013). As the industrial processes in the country evolve from exploration of petroleum to refining of crude oil and the arrival of the finished products, workers involved in the production process are often exposed to severe safety and health problems (Sergeant et al 2003; Carneiro et al 2014; Government of Trinidad and Tobago 2013; Allen \& Dibie 2016;. The petrochemical workers are often exposed to many and varied health hazard, accidents, injuries with heavy tools and equipment. There has also been several incidents of pipeline explosion, fire and transportation accidents as well as ergonomic conditions (Mulchansingh 1971; Sergeant 2003; Government of Trinidad and Tobago 2014). The World Health Organization Report (2002) reveals that among all occupations, industrial and agricultural workers have the highest risk. Further, to the best of the researchers' knowledge there has never been any recent study to assess occupational hazard and safety of petrochemical workers in the past ten years in Trinidad and Tobago. Therefore, one of the aims of this study is to assess the pattern of occupational hazard and safety compliance and effectiveness among workers in the petrochemical and construction industries in the country.

In Trinidad and Tobago, no major effort has been taken since 2004 or 2006 to determine the efficacy of any particular configuration of worker protection and participatory rights. 
Measuring OSH outcomes in a particular jurisdiction is notoriously difficult because of the absence of reliable measures that are not plagued by reporting problems (Allen \& Dibie 2016). These difficulties multiply when comparing jurisdictions that have different injury-reporting systems (Government of Trinidad and Tobago 2013; Sergeant 2003). Although there is empirical evidence that the combination of strong participation and protection rights improves health and safety performance there are no mandated guidelines or regulations to perform activities inside greenhouses (Friis 2019; Maxwell 2018; Levy et al 2011). There continues to be very limited data on occupational safety and health practices that relates to the use of pesticides in Trinidad and Tobago.

What is missing in the literature of occupational safety and health issues in Trinidad and Tobago is that research among construction and manufacturing workforce has been limited. At the same time occupational health studies have been gaining increasing attention in the United States, Canada, and Western Europe but not in the Caribbean islands' countries. Unfortunately, no previous efforts have been made to assess the occupational safety and health of the construction, manufacturing and petrochemical industries in Trinidad and Tobago. Therefore, this paper will provide some insights into the OSH problems faced by workers in three industrial areas in Trinidad and Tobago.

This paper will examine the effectiveness of the occupational safety and health policy in the construction, manufacturing, and petrochemical industrial sectors in Trinidad and Tobago. It argues that inadequate enforcement of the OSH policy, oversight, and accountability strongly suggests that the Government of Trinidad and Tobago is not serious about its OSH policy. It will also seek to provide a scientific basis for improving the OSH policy in Trinidad and Tobago. It is widely acknowledged that a credible evidence-based approach that is integral to sustainable developing is a platform adopt (Benjamin \& Greef 1997; Lavicoli et al 2011). An evidence-based approach that broadly informs professional opinion and guides policy formulation could be alternative solution as well. There is the need not only to evaluate characterize the current status of the OSH policy in Trinidad and Tobago, but also to analyse its historical evolution over a defined period, by linking identified developments to regional and sub-regional growth. The need to collate and analyse all available information about the OSH strategies and policies that were developed for the English-speaking Caribbean countries from 1990 to 2012 thereby arises. There is also the need to evaluate their impact based on objective criteria. The criteria to be used will be selected based on established OSH policy development and evaluation framework.

\section{Occupational Safety and Health Conceptual Framework}

The policies of government and international agencies directly impact the environment and occupational safety and health (Kraft \& Furlong, 2018). According to Thomas Dye (2013) and Davies and Mazumder (2003) policy instruments represent the means to achieve sustainable development goals. Several scholars have identified different categories of policy instrumentation to include (1) regulation, (2) market and incentive-based; (3) information provision; (4) taxing and spending; (5) education; (6) rationing; (7) privatization; (8) charging fees; (9) purchasing goods and services; (10) creation of public trust; (11) support research 
and development; and (12) assessment of damages (Kraft, 2010; Kraft \& Furlong 2018; Levy et al 2011; Taylor 2012). As appealing as some of the alternative approaches are, most come with limitations or disadvantages as well as advantages. As a result, public policy could be viewed as a political instrument for solving a nation's citizens' problems. At best public policies could explore various alternatives and select the most appropriate options to effectively address an identified problem in a regional or national government (Kraft \& Furlong 2018; Dibie 2014).

The precautionary principle postulates that rather than demonstrate harm as ground to regulate a chemical or process after it is use, human being should take steps to prevent or minimize harm from outset (Maxwell 2014; Friis 2019). The principle acknowledges our common-sense notion about taking precaution. For example, look before you leap or better be safe than to be sorry (Kriebel et al, 2001). The principle embodies the longstanding preference in public health for primary prevention over secondary prevention whenever possible (UNESCO, 2005). Efforts towards primary prevention are aimed to head off health problems before they happen (Kriebel et al, 2001; Friis 2019; Friis, 2016). The precautionary principle tie society's goals, to the extent to which its negative impacts can be prevented while meeting the social goals. The principle also proposed that government should explore other ways to meet society's goal with less risk (Kriebel et al, 2001). The precautionary principle mandate regulatory authorities such as environment management Agency and the Ministry of Health in Trinidad and Tobago to re-evaluate a safety problem when there is sufficient evidence to suggest a potential negative impact.

The systems approach to OSH stipulates that within companies, junior managers, supervisors and workers on the shop floor take their cue from the top. According to Hermanus (1999) and Willis (1985) companies' executives in their boardroom have the influence, power and resources to take the initiative and set the pattern of safety and health in any organization. As a result, reduction in the occurrence of occupational injury and disease in any industrial company may be sought by adopting a systematic approach to prevention. Such initiatives may involve the identification of hazards, the planning and monitoring of preventive measures, and integrating health and safety related criteria into routine work and decision-making all over any company or organization (Hermanus, 1999).

In the past five decades several countries have enacted the occupational safety and health policy. For instance, the occupational safety and health Act in the United States were enacted in 1970 (Taylor et al 2012; Levy et al 2011). Because of the OSHA Act of 1970, a regulatory or enforcement agency called the Occupational Safety and Health Administration (OSHA) was established (Taylor et al 2012). In addition, the National Institute for Occupational Safety and Health (NIOSH) was also established to provide research and technical assistance (Levy et al 2011). The National Advisory Committee on Occupational Safety and Health (NACOSH) was appointed. Representatives of both labor and management are included amongst the members of the advisory committee (Ashford, 1976).

The British Health and Safety at Work Act was enacted in 1974. The Health and Safety Commission (HSC) a tripartite policy-making institution was set up together as its inspection 
and enforcement agency in 1974. The Health and Safety Executive (HSE) coordinated the implementation of the policy (Dawson et al. 1988).

The Swedish government enacted its Workers Protection policy in 1949. In the 1970s, Sweden also created the Worker Protection Board, an independent agency which was established under the Worker Protection Act of 1949 to oversee the formulation, enforcement and regulations (Kelman1981). In 1978 a new law, the Working Environment Act was passed (Oscarsson, 1985). In other parts of Scandinavia, namely Norway and Denmark similar laws were adopted in the mid-1970s (Gibbs, 2000, Benjamin and Greef, 1997). In Italy, worker participation and protection from health and safety hazards were boosted by the Worker's Statute of 1969 and the National Health Service Law of 1978 (Misiti \& Bagnara 1985). In Germany legal and workers safety and health policies were also established in the 1970s (Naschold, 1985). Other countries in which similar OSH policy reforms were undertaken include France, Belgium, the Netherlands and Finland (Ashford, 1976).

As a result of the enactment of occupational safety and health policies in the United States and a few European countries in the 1970s several other nations embarked on the formulation of similar policies in the 1980s, 1990s and beyond, most notably Canada, Australia, New Zealand, Namibia, Lesotho, Swaziland, Malaysia, Zimbabwe, Hong Kong, South Africa and Trinidad and Tobago (Dibie, 2014). These regulatory agencies in the above countries are expected to monitor and be involved in the enforcement, compensation and prevention of accident occurrence in the workplace (Moreau \& Neis, 2009). Thus, the timely information on hazards and the best methods to eliminate or reduce hazard is a fundamental requirement of the various OSH policies.

In the past few decades, there has been major debate over what OSH management systems entail in practice and whether they are of real value (Maxwell 2014; Friis 2019). Despite these debates, some scholars argue that occupational, safety and health management systems can prevent the occurrence of injury and disease at the workplace (Whithgott \& Brennan 2008; Tyler \& Spoolman 2012). An investigation into the relationship between health and safety performance and OSH management systems in the manufacturing and construction industry of many countries, suggests that effective systems should include: (1) engage worker OSH representatives broadly and actively; (2) involve comprehensive workplace inspections and incident investigation; (3) clearly define and assign OSH responsibilities; (4) approach hazard identification and risk assessment in a planned way; and (5) give priority to the control of hazards at source (Hermanus 1999; Waller \& Jones 2002). Figure 1 shows the model of work design hazards in five industries 


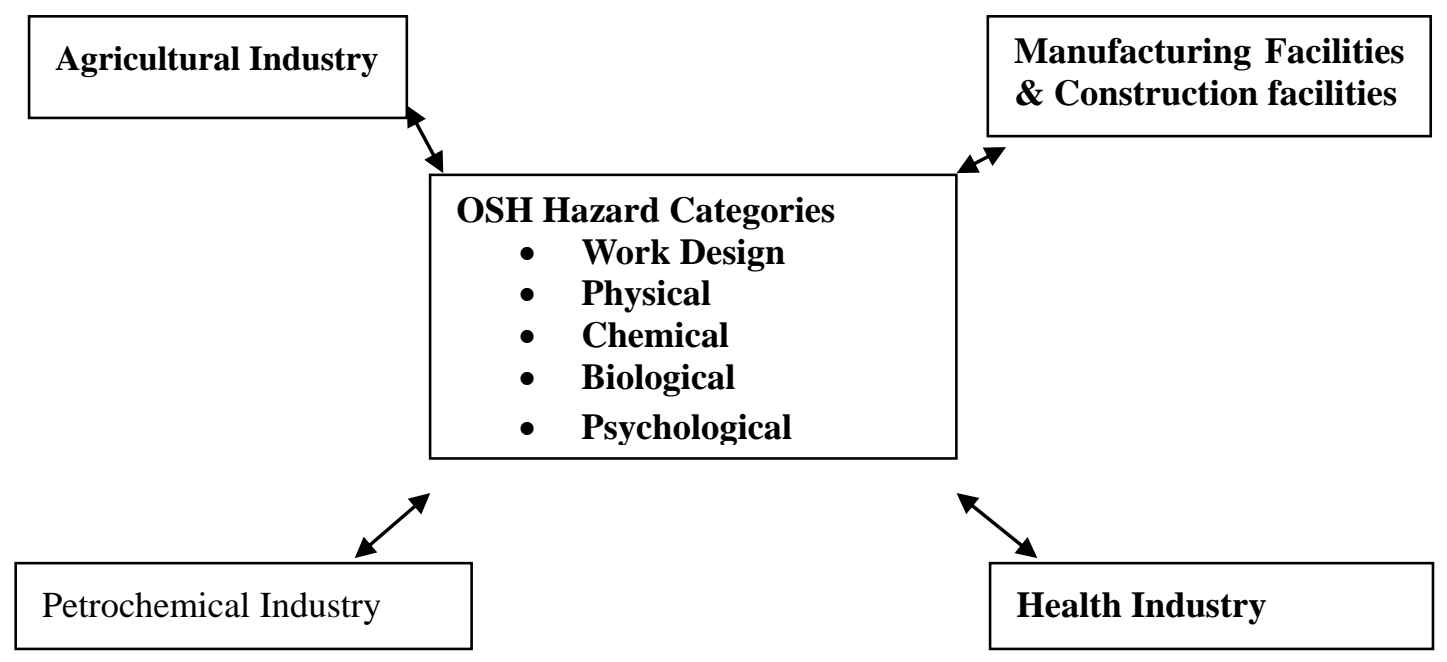

Figure 1. Model of Work Design Hazards in five industries

Source: Adopted from Moreau, D. and B. Neis. (2009). "Occupational Health and Safety Hazards in Atlantic Canada Aquaculture: Laying the Groundwork for Prevention." Marine Policy 33, pp. 401-411.

Figure 1 shows the work designed hazard model. The model could be used to explain the fact that poorly designed workplaces and workstations that requires heavy lifting prolong standing, awkward posture and repetitive work could be associated with high risk and health disorder (Levy et al 2011). These health disorders can affect both upper and lower limbs, neck and shoulder pain, low back pain, bursitis, tendonitis, carpel tunnel syndrome and tenosynments (Maxwell, 2014). According to Moreau and Neis (2009) there are evidences of these work design hazard in many industrial sectors where basic health and safety guidelines have been implemented.

The environment and human relations theory argue that the relationship between workers' health and the environment is mostly associated with their exposure to pollution agents (Mark-Davies \& Mazumder, 2003). For example, the management and treatment of waste generated from human activities include leftovers from industrial waste, and urbanization predicaments. All levels of government and industries that employ workers bear the responsibility for setting policies to ensure the protection of water resources and for providing instruments for the attainment of these health safety policies (Samson, 2002).

Ecological modernization theory proposed that policies for economic development and environmental protection can coexist synergistically, establishing a positive-sum game between economy and ecology (Gouldson \& Murphy 1997; Maxwell 2014). Instead of viewing environmental protection to mean a brake on growth, ecological modernization sponsors the application of strict environmental policy as a positive influence on economic efficiency and technological modernization (Gouldson \& Murphy, 1997). Hajer (1996) observed, that 'economic growth and the resolution of ecological problems can, in principle, be reconciled.' Dryzek (1997) on the other hand opined that ecological modernization 'has a much sharper focus than does sustainable development on exactly what needs to be done with 
the capitalist political economy.' Dryzek (1997) further argued, that a world that is indomitable by free trade, capital mobility and great dedication to market liberalization could create more environmental problems if appropriate policies are not enacted to check the activities of human beings and corporations. Thus, ecological modernization is expected to provide both a theoretical and practical guide to a suitable response for environmental challenges (Mol 2001; Gibbs, 2000). Figure 2 shows the relationship between OSH Policy, Health and the environment.

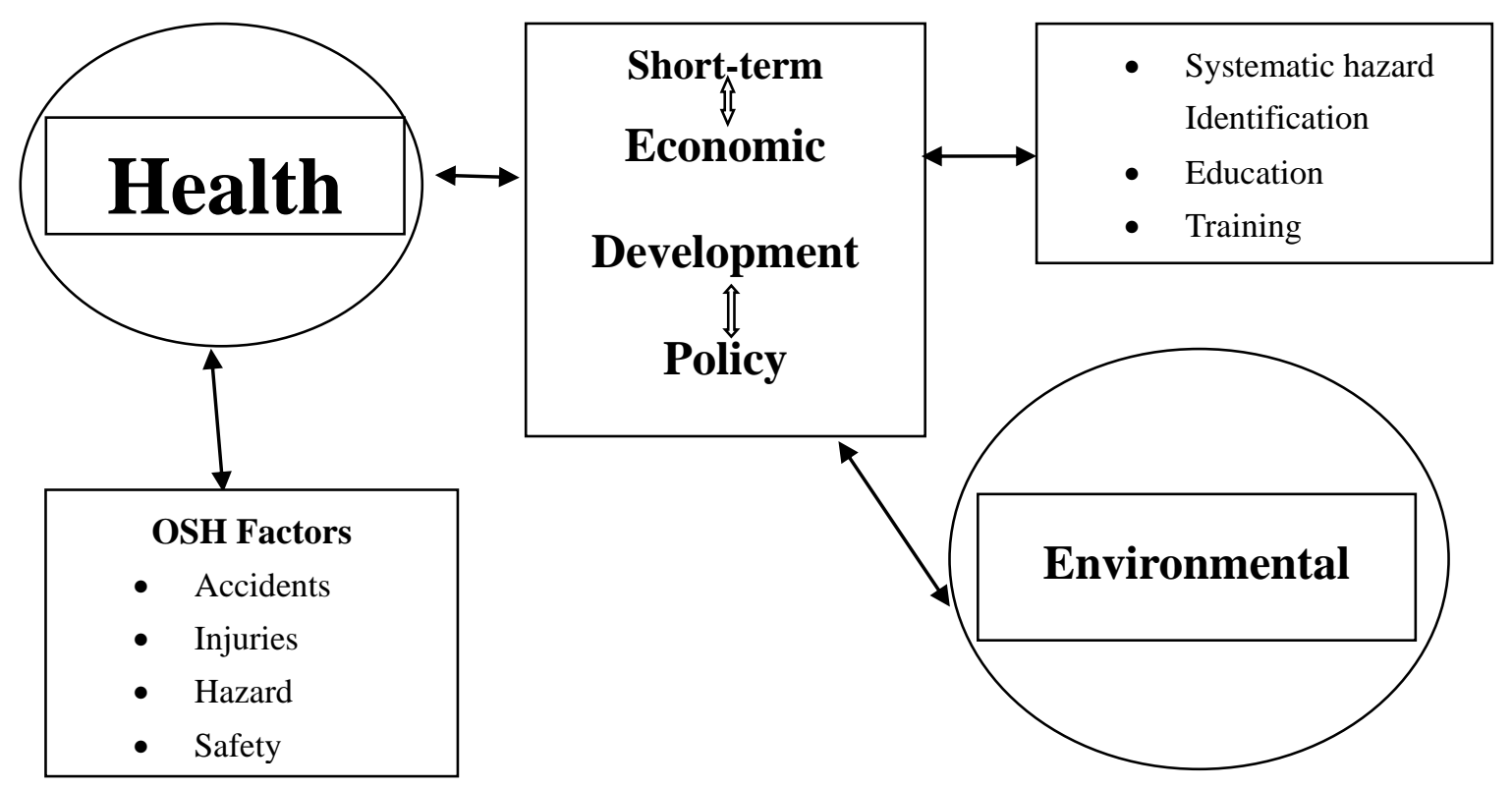

Figure 2. Model of Relationship between OSH Policy, Health and the Environment

Source: Adopted from Dibie R. (2014). Comparative Perspective on Environmental Policy and Issues. New York, NY: Routledge Press

Samson (2002) contends that at the public policy level, there should be a strong desire to improve the understanding of the various relationships between human health and the environment. There is no doubt therefore to argue that environmental degradation and negligence could galvanize serious human health problems. Long-term human health issues are mostly related to chemicals and physical agents for example Radon. Those of particular interest include DBPs (Mark-Davies \& Mazumder, 2003). Systematic hazard identification, education, training and prevention are essential. This research will provide a solid framework for advancing occupational safety and health promotion activities in Trinidad and Tobago given the current challenges.

\section{Research Method}

This paper uses interview and questionnaire data to evaluate the effectiveness of the occupational safety and health policy in three industrial areas in Trinidad and Tobago. It specifically explored the impact of the OSH policy in the (1) Construction; (2) Manufacturing; and (3) Petro-chemical industries. Primary data were derived through questionnaire surveys and interviews. Secondary data was sought from books, periodic reports, journals and other 
publications from libraries and the internet.

The questionnaires were administered to 1,500 respondents drawn from the staff of the three industrial sectors under study. The respondents were randomly selected from the three industries under study in Trinidad and Tobago. However only 1,046 (69.7\%) respondents completed and returned the questionnaire. Data collected were analysed with SPSS statistical tool and presented in correlations, frequency tables and percentile. The questionnaire was designed to capture data relevant to the research hypotheses and objectives. It predominantly comprised of closed ended questions, which along with two (2) open ended questions to capture information in eight (8) categories. These categories were demographic details; hazard exposures; impact/outcome of exposures on workers; employer actions regarding worker wellbeing following workplace injuries and illnesses; awareness of national OSH policy requirements; management action and worker participation in OSH; OSH Agency policy implementation actions; and outcome of OSH Agency actions.

A total of three hundred and seventy seven (377) one-on-one interviews were conducted in the construction, manufacturing and petrochemical industrial sectors in Trinidad and Tobago. In order to obtain a true reflection of the health and safety knowledge at the respective industries, senior and junior employees were interviewed. Non-industry officials interviewed included OSH Authority and Agency officials, Workmen Compensation Board officials, National Safety Council executives, Industrial Court judges and staff, insurance industry officials, Trade Unionists, lawyers, agricultural society officials, and academic staff that was involved in OSH curricula. The identities of the interview participants were kept confidential.

There was little reliance on secondary data in this study. Notwithstanding, the researcher attempted to obtain occupational accident and illness statistics, injury and illness compensation data, information about OSH offenses and prosecutions including Industrial Court statistics, and OSH Key Performance Indicators for each of the sectors under study. Each organization was visited and the personnel who were responsible for data management were interviewed so as to obtain a full understanding of the reliability, validity and comprehensiveness of available datasets. The hypothesis are:

Hypothesis 1. There is a positive relationship between the OSH policy and workers'safety and health in Trinidad and Tobago.

Hypothesis 2. There is a positive relationship between the OSH policy and workers' contribution to the sustainable development of Trinidad and Tobago:

The independent variable is OSH Policy in Trinidad and Tobago. The dependent Variables are the impacts of the OSH policy on workers in the (a) construction, (b) manufacturing and (c) petro-chemical industries.

The Limitations of this research is that several companies that were selected at random to participate in the study did not facilitate data collection. There were two reasons: (1) Employers did not want to create employee awareness or heightened awareness about employer duties and responsibilities as outlined in the national OSH policy; and (2) Employers were sensitive about their reputation and corporate image regarding their degree 


\section{Macrothink}

Journal of Public Administration and Governance

ISSN 2161-7104

2019, Vol. 9, No. 4

of compliance with the national OSH policy. Several workers were also unwilling to facilitate data collection. Some were shift workers who found it difficult to identify free time to participate in one-on-one discussions. Others were unwilling to participate for fear that somehow their employers would have become aware of their responses.

\section{Data Analysis and Discussion}

One thousand five hundred $(1,500)$ survey questionnaires were distributed and one thousand and forty-six $(1,046)$ were returned. The response rate was 69.7\%. Twenty-five (454) questionnaires were incomplete and were not included in the analysis. Eight hundred and thirty-one (831) were completed in Trinidad and two hundred and fifteen (215) were completed in Tobago. The breakdown of questionnaires by industrial sector was as follows: (1) Petrochemical 317; (2) Manufacturing 328; (3) Construction 186; and Tobago Island 215.

\section{Distribution of Returned Questionnaires by Sector}

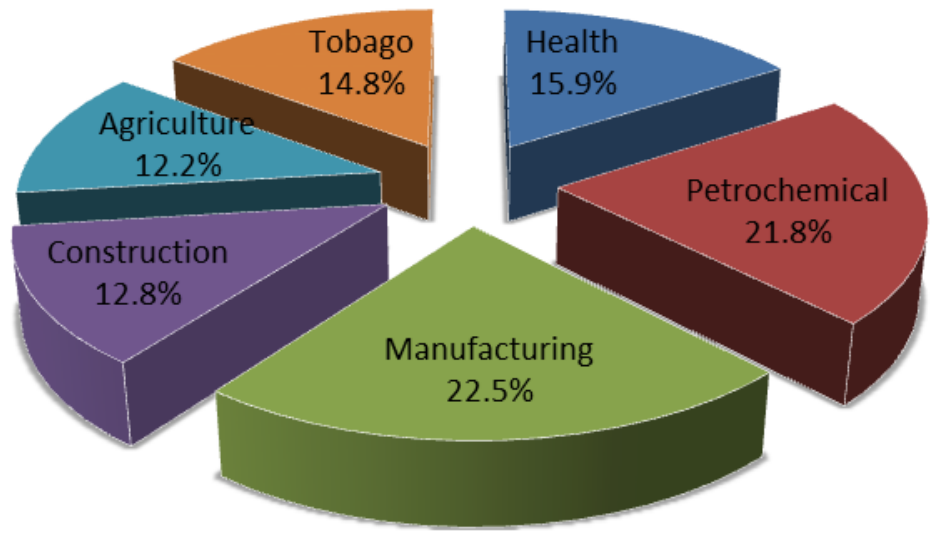

Figure 3. Distribution of Returned Questionnaire by Industrial Sector

Derived from SPSS Analysis in 2018

More than sixty percent (60\%) of the respondents in each sector were employed for greater than five (5) years and more than thirty percent (30\%) were employed for more than (10) years. The majority of respondents in all sectors were permanent workers. The construction sector employed largest percentage of temporary and contract workers. Tobago followed by the construction sector had the largest percentage of managerial level respondents.

This research also used interview as an instrument for collecting data. Three hundred and seventy-seven (377) one-on-one interviews were conducted in Trinidad and Tobago. The breakdown of interviews by sector was as follows: (1) Petrochemical 119; (2) Manufacturing 118; (3) Construction 69; and (4) Tobago Island 22. Figure 4 show employment category. 


\section{Analysis of Hypothesis 1}

Hypothesis 1: There is a positive relationship between the OSH policy and workers' safety and health in Trinidad and Tobago.

\section{Construction Industry:}

\section{Interview:}

Seventy-six percent $(76 \%)$ of the interview respondents indicated that there were a lot of positive changes in the construction industry due to the enactment of the national OSH policy in 2004 and amended in 2006. Job sites became safer, workers generally became more safety conscious and there has been a positive change in safety behavior. Respondents contend however that these changes were not universal in that there was a greater tendency for larger construction companies to work towards compliance than what occurred at smaller companies.

There is also a positive perception that the new OSH policy in good for the country. In this regard $81 \%$ of the interviewed respondents in the construction industry stated that foreign construction companies operating in Trinidad and Tobago and the large local contractors that worked for them made greater efforts to adhere to good health and safety standards. This had been occurring even prior to the national policy.

While $63 \%$ of the respondents indicated that because the national OSH policy provided workers with the option to refuse to perform unsafe work in situations where they felt that their health and safety was at risk. Thus, not all the workers have been able to refuse high risk assignment due fear of been layoff. On the other hand, however only $37 \%$ of the respondent indicated that when some workers attempted to abuse the above provision of the OSH policy they were victimized by their employers when they complained about hazardous conditions of work and unsafe practices.

\section{Questionnaire:}

Approximately forty-six percent $(46.4 \%)$ of the respondents felt that their health and safety was at risk. Approximately fifty-five percent (54.9\%) were somewhat satisfied with their working conditions and just over seventy-three percent (73.2\%) felt that their employers were actively trying to improve conditions. This is shown in Table 1 below.

Table 1. Health \& Safety Risk and Employer Actions

\begin{tabular}{|l|l|l|l|}
\hline \multirow{3}{*}{ Question 11} & How well informed are you about Health & Very well informed & $50.0 \%$ \\
\cline { 3 - 4 } & and Safety risks related to the & Well informed & $41.7 \%$ \\
\cline { 3 - 4 } & performance of your job? & Not well informed & $7.8 \%$ \\
\cline { 3 - 4 } & & Don't know & $0.6 \%$ \\
\hline \multirow{2}{*}{ Question 13 } & Have you received Health and Safety & Strongly agree & $32.2 \%$ \\
\cline { 3 - 4 } & training? & Agree & $59.9 \%$ \\
\cline { 3 - 4 } & & Disagree & $5.6 \%$ \\
\cline { 3 - 4 } & & Strongly disagree & $1.7 \%$ \\
\hline
\end{tabular}




\begin{tabular}{|c|c|c|c|c|}
\hline & & Undecided & $0.6 \%$ & \\
\hline \multirow[t]{3}{*}{ Question 36} & \multirow{3}{*}{$\begin{array}{l}\text { Do you think that your Health and Safety } \\
\text { is at risk? }\end{array}$} & Yes & \multicolumn{2}{|l|}{$46.4 \%$} \\
\hline & & No & \multicolumn{2}{|l|}{$44.8 \%$} \\
\hline & & Don't know & \multicolumn{2}{|l|}{$8.8 \%$} \\
\hline \multirow{3}{*}{ Question 37} & \multirow{3}{*}{$\begin{array}{l}\text { On the whole, how satisfied are you with } \\
\text { the working conditions at the company } \\
\text { you work for? }\end{array}$} & Very satisfied & \multicolumn{2}{|l|}{$33.5 \%$} \\
\hline & & Somewhat satisfied & \multicolumn{2}{|l|}{$54.9 \%$} \\
\hline & & Not at all & \multicolumn{2}{|l|}{$11.5 \%$} \\
\hline \multirow{4}{*}{ Question 43} & \multirow{4}{*}{$\begin{array}{l}\text { Do you think that your employer is } \\
\text { actively trying to improve working } \\
\text { conditions? }\end{array}$} & Yes, a lot & $36.5 \%$ & \multirow[b]{2}{*}{$73.2 \%$} \\
\hline & & Yes, a little & $36.6 \%$ & \\
\hline & & Not sure & $18.5 \%$ & \multirow[b]{2}{*}{$26.9 \%$} \\
\hline & & Not all & $8.4 \%$ & \\
\hline
\end{tabular}

\section{Correlational Analysis}

A weak correlation was observed between "Workplace Committees" and "Risk": Pearson Correlation coefficient $.175, \mathrm{p}=0.05$. This suggests that Construction workers tended to report less exposure to hazards in the workplaces where there were Health and Safety committees. This is shown in Table 2 below.

Table 2. Correlation Matrix

\begin{tabular}{|c|c|c|}
\hline & Risk Index & Issues at Work \\
\hline Policy Index & 0.145 & -0.091 \\
\hline Safety Committees & $0.175^{*}$ & $-0.211^{* *}$ \\
\hline Wellness Initiatives & 0.053 & 0.03 \\
\hline
\end{tabular}

** Correlation is significant at the 0.01 level (2-tailed)

* Correlation is significant at the 0.05 level (2-tailed)

Manufacturing Industry

\section{Interview:}

Eight five percent $(85 \%)$ of the interviewed respondents in the manufacturing industry felt that the national OSH policy had greater impact on local manufacturing companies than it did on international companies that operated in Trinidad and Tobago. International companies were required to comply with corporate and international OSH standards and as a consequence had already entrenched safety management systems within their operations.

Further $61 \%$ of the respondents indicated that there was a positive difference since the OSH policy was enacted, because there was a greater attempt to safeguard workers. Some amount of safety management was traditionally practiced, particularly in factories where there were very hazardous materials and processes. This was done to minimize accidents and equipment malfunction that threatened business interruption. However, the scope of OSH activities expanded post the OSH policy and there was a more serious approach to safety in some 
companies.

Another $67 \%$ of respondents indicated that many workers often tend to disregard safety because they perceived that their employers did not consider them to be valuable and were not truly committed to protecting them. They believed that they were of low value because they were required to endure unsuitable conditions of work and received minimum wages and few perks.

In addition, 33\% of the respondents indicated that most manufacturing companies where they have worked are not in compliant with the national OSH policy's requirement to report incidents to the regulatory agency. They feared that reporting would attract negative scrutiny, or that fines would have been applied or uncomplimentary publicity would have been the outcome of OSH Agency investigations.

\section{Questionnaire:}

Approximately thirty-six percent $(36.3 \%)$ of the respondents felt that their health and safety was at risk. Approximately sixty-seven percent (66.5\%) were somewhat satisfied with their working conditions and $75.3 \%$ felt that their employers were actively trying to improve conditions. Table 3 show the health and safety risk, as well as employers' action in the manufacturing industry questionnaire data.

Table 3. Health \& Safety Risk and Employer Actions

\begin{tabular}{|c|c|c|c|c|}
\hline \multirow{4}{*}{ Question 11} & \multirow{4}{*}{$\begin{array}{l}\text { How well informed are you about Health } \\
\text { and Safety risks related to the performance } \\
\text { of your job? }\end{array}$} & Very well informed & \multicolumn{2}{|l|}{$23.3 \%$} \\
\hline & & Well informed & \multicolumn{2}{|l|}{$52.8 \%$} \\
\hline & & Not well informed & \multicolumn{2}{|l|}{$21.4 \%$} \\
\hline & & Don't know & \multicolumn{2}{|l|}{$2.5 \%$} \\
\hline \multirow{5}{*}{ Question 13} & \multirow{5}{*}{$\begin{array}{l}\text { Have you received Health and Safety } \\
\text { training? }\end{array}$} & Strongly agree & \multicolumn{2}{|l|}{$17.7 \%$} \\
\hline & & Agree & \multicolumn{2}{|l|}{$51.1 \%$} \\
\hline & & Disagree & \multicolumn{2}{|l|}{$18.6 \%$} \\
\hline & & Strongly disagree & \multicolumn{2}{|l|}{$8.7 \%$} \\
\hline & & Undecided & \multicolumn{2}{|l|}{$3.9 \%$} \\
\hline \multirow[t]{3}{*}{ Question 36} & \multirow{3}{*}{$\begin{array}{l}\text { Do you think that your Health and Safety is } \\
\text { at risk? }\end{array}$} & Yes & \multicolumn{2}{|l|}{$36.3 \%$} \\
\hline & & No & \multicolumn{2}{|l|}{$49.2 \%$} \\
\hline & & Don't know & \multicolumn{2}{|l|}{$14.5 \%$} \\
\hline \multirow[t]{3}{*}{ Question 37} & \multirow{3}{*}{$\begin{array}{l}\text { On the whole, how satisfied are you with } \\
\text { the working conditions at the company you } \\
\text { work for? }\end{array}$} & Very satisfied & \multicolumn{2}{|l|}{$21.9 \%$} \\
\hline & & Somewhat satisfied & \multicolumn{2}{|l|}{$66.5 \%$} \\
\hline & & Not at all & \multicolumn{2}{|l|}{$11.6 \%$} \\
\hline \multirow{4}{*}{ Question 43} & \multirow{4}{*}{$\begin{array}{l}\text { Do you think that your employer is actively } \\
\text { trying to improve working conditions? }\end{array}$} & Yes, a lot & $32.9 \%$ & \multirow[b]{2}{*}{$75.3 \%$} \\
\hline & & Yes, a little & $42.4 \%$ & \\
\hline & & Not sure & $18.4 \%$ & \multirow[b]{2}{*}{$24.7 \%$} \\
\hline & & Not all & $6.3 \%$ & \\
\hline
\end{tabular}




\section{Correlational Analysis}

The relationship between the OSH policy (dependent variable) and impact on worker safety and health (independent variables) was investigated using correlation analysis. A weak correlation was observed between "Wellness Initiatives" and "Risk": Pearson Correlation coefficient .124, $\mathrm{p}=0.05$. This suggests that workers tend to report less exposure to occupational hazards in the workplaces where Wellness Initiatives were implemented. Table 4 show the correlation analysis.

Table 4. Correlation Matrix

\begin{tabular}{|c|c|c|}
\hline & Risk Index & Issues at Work \\
\hline Policy Index & $0.385^{* *}$ & $-0.220^{* *}$ \\
\hline Safety Committees & 0.016 & -0.071 \\
\hline Wellness Initiatives & $0.124^{*}$ & -0.008 \\
\hline
\end{tabular}

** Correlation is significant at the 0.01 level (2-tailed)

*Correlation is significant at the 0.05 level (2-tailed)

Petro-chemical Industry

Interview:

Multinational Petro-chemical companies, state owned and operated companies, and a number of lease operators and service companies operate in Trinidad and Tobago. Sixty eighty percent $(68 \%)$ of the interview respondents felt that the national policy did not have a significant impact on HSE management or on safety culture within multinational companies and local companies that had large multinational shareholding. It was felt that these companies had been adhering to high corporate HSE standards prior to the national OSH Policy, and that they continued to subscribe to their fundamental OSH management systems while meeting and in many instances exceeding the national policy's requirements.

However, $32 \%$ of the Interview respondents reported that the policy had greater impact on local companies. In some of these local companies the OSH policy improved management perception of the importance of OSH, and brought about greater support for safety initiatives. Systems for protecting employees improved in many local companies and there was a decrease in accidents and related down time. OSH risk assessments were undertaken much more frequently and were more in-depth. There was increased focus on the health aspects including indoor air quality, welfare, and medical surveillance, and many companies sought to improve safety culture. Collaboration for safety management amongst OSH personnel also increased.

Many large companies contracted out a lot of their plant maintenance work to service companies. Much of this work was inherently high hazard. Seventy-seven (77\%) of the respondents felt that many contractors were not sufficiently focusing on OSH, and this caused multinational and large companies to improve their contractor safety management systems. 


\section{Questionnaire:}

Approximately forty-five percent of the respondents (44.8\%) felt that their health and safety was at risk. Sixty-three percent $(63.3 \%)$ were somewhat satisfied with their working conditions and $76.5 \%$ felt that their employers were actively trying to improve conditions. Table 5 show the health and safety risk, as well as employers' action in the petrochemical industry questionnaire data.

Table 5. Health \& Safety Risk and Employer Actions

\begin{tabular}{|c|c|c|c|c|}
\hline \multirow{4}{*}{$\begin{array}{l}\text { Question } \\
11\end{array}$} & \multirow{4}{*}{$\begin{array}{l}\text { How well informed are you about Health and } \\
\text { Safety risks related to the performance of your } \\
\text { job? }\end{array}$} & Very well informed & \multicolumn{2}{|l|}{$47.9 \%$} \\
\hline & & Well informed & \multicolumn{2}{|l|}{$47.6 \%$} \\
\hline & & Not well informed & \multicolumn{2}{|l|}{$3.8 \%$} \\
\hline & & Don't know & \multicolumn{2}{|l|}{$0.6 \%$} \\
\hline \multirow{5}{*}{$\begin{array}{l}\text { Question } \\
13\end{array}$} & \multirow{5}{*}{ Have you received Health and Safety training? } & Strongly agree & \multicolumn{2}{|l|}{$42.8 \%$} \\
\hline & & Agree & \multicolumn{2}{|l|}{$51.8 \%$} \\
\hline & & Disagree & \multicolumn{2}{|l|}{$5.1 \%$} \\
\hline & & Strongly disagree & \multicolumn{2}{|l|}{$0.0 \%$} \\
\hline & & Undecided & \multicolumn{2}{|l|}{$0.3 \%$} \\
\hline \multirow{3}{*}{$\begin{array}{l}\text { Question } \\
36\end{array}$} & \multirow{3}{*}{$\begin{array}{l}\text { Do you think that your Health and Safety is at } \\
\text { risk? }\end{array}$} & Yes & \multicolumn{2}{|l|}{$44.8 \%$} \\
\hline & & No & \multicolumn{2}{|l|}{$45.1 \%$} \\
\hline & & Don't know & \multicolumn{2}{|l|}{$10.2 \%$} \\
\hline \multirow{3}{*}{$\begin{array}{l}\text { Question } \\
37\end{array}$} & \multirow{3}{*}{$\begin{array}{l}\text { On the whole, how satisfied are you with the } \\
\text { working conditions at the company you work } \\
\text { for? }\end{array}$} & Very satisfied & \multicolumn{2}{|l|}{$28.1 \%$} \\
\hline & & Somewhat satisfied & \multicolumn{2}{|l|}{$63.3 \%$} \\
\hline & & Not at all & \multicolumn{2}{|l|}{$8.6 \%$} \\
\hline \multirow{4}{*}{$\begin{array}{l}\text { Question } \\
43\end{array}$} & \multirow{4}{*}{$\begin{array}{l}\text { Do you think that your employer is actively } \\
\text { trying to improve working conditions? }\end{array}$} & Yes, a lot & $36.6 \%$ & \multirow[b]{2}{*}{$76.5 \%$} \\
\hline & & Yes, a little & $39.9 \%$ & \\
\hline & & Not sure & $18.0 \%$ & \multirow[b]{2}{*}{$23.6 \%$} \\
\hline & & Not all & $5.6 \%$ & \\
\hline
\end{tabular}

\section{Correlational Analysis}

The relationship between the OSH policy (dependent variable) and impact on worker safety and health (independent variables) was investigated using correlation analysis. Table 6 show the correlation analysis. A weak correlation was observed between "Workplace Committees" and "Risk": Pearson Correlation coefficient .138, $\mathrm{p}=0.05$. This suggests that Petro-chemical workers tended to report less exposure to occupational hazards in the workplaces where there were Health and Safety committees.

Table 6. Correlation Matrix

\begin{tabular}{|c|c|c|}
\hline & Risk Index & Issues at Work \\
\hline Policy Index & $0.364^{* *}$ & $-0.416^{* *}$ \\
\hline Safety Committees & $0.138^{*}$ & $-0.280^{* *}$ \\
\hline Wellness Initiatives & $0.117^{*}$ & $-0.170^{* *}$ \\
\hline
\end{tabular}


** Correlation is significant at the 0.01 level (2-tailed)

*Correlation is significant at the 0.05 level (2-tailed)

\section{Major Findings of Hypothesis 1}

This section analyzes the Interview and Questionnaire data that are relevant to Hypothesis 1.

Hypothesis 1: There is a positive relationship between the OSH policy and workers' safety and health in Trinidad and Tobago.

\section{Construction Industry}

Interview respondents reported that the national OSH policy brought about several positive changes whereas focus group participants reported that many unsafe conditions and practices still existed. This difference in views was also reflected in the questionnaire responses in that almost half $(46.4 \%)$ of the respondents felt that their health and safety was at risk. However, over seventy-three percent $(73.2 \%)$ of respondents indicated that their employers were actively trying to improve working conditions.

A weak correlation was identified in the questionnaire analysis that hazard exposure decreased as safety committees increased. The questionnaire data also suggests that there is a positive relationship between the OSH policy and workers' safety and health in the Construction sector.

\section{Manufacturing Industry}

Analysis of the questionnaire data revealed that approximately sixty-seven percent $(66.5 \%)$ of the respondents were somewhat satisfied with their working conditions and approximately seventy-five $(75.3 \%)$ felt that their employers were actively trying to improve conditions. In addition, $45 \%$ Interview respondents indicated that workers tend to disregard safety. Data collected from all sources indicated that a lot was still to be done to improve conditions of work, and to bring about real management commitment for OSH that was not directly linked to apprehension or imposition of punitive measures for policy non-conformances. Though several compliance gaps were identified, the overall data revealed that there is a weak positive relationship between the OSH policy and workers' safety and health in the manufacturing industry.

\section{$\underline{\text { Petrochemical Industry }}$}

Interview respondents agreed that the national OSH policy resulted in improved health and safety. This was supported by the questionnaire data which revealed that over seventy-six percent $(76 \%)$ of employers were actively trying to improve working conditions. The correlation analysis revealed that there was decreasing exposure to risk in workplaces where there was increasing compliance with the policy's requirement to establish Health \& Safety committees. This, even though approximately forty-five percent (44.8\%) of questionnaire respondents indicated that their health and safety was at risk.

In addition, the multinational companies were less impacted by the national OSH policy than 
were local companies because most had traditionally been pursuing compliance with their own corporate Health and Safety standards, and international standards. Improvements reported within local companies included improved management perception of the importance of OSH, improved risk assessment, improved OSH resourcing, and decreased incidence of loss events. Interview respondents also reported that the policy brought about increased OSH consciousness and heightened awareness of the existence of legislative penalties for non-compliance, across the sector.

There were increased attempts by workers to abuse the policy's provision to refuse to do unsafe work. There was also agreement that large companies tended to contract out hazardous jobs and were constantly challenged to manage contractor safety. Research hypothesis 1. is accepted. There is a positive relationship between the OSH policy and workers' safety and health in the Petrochemical sector.

\section{Analysis of Hypothesis 2}

Hypothesis 2: There is a positive relationship between the OSH policy and workers' contribution to the sustainable development of Trinidad and Tobago:

\section{Construction:}

Interview:

Approximately $79 \%$ respondents interviewed in the construction industry indicated that accidents continued to occur but there was a reduction in serious accidents post the enactment of the policy. However, $21 \%$ of the respondents stated that there has been a decline in the accidents that occurred compared to three or more years ago for workers. On the other hand, $66 \%$ of the respondents stated that they have used the OSH policy provisions as an excuse to refuse to perform unsafe work.

Eighty-one $(81 \%)$ of the respondents also indicated that the costs involved in providing personal protective equipment (PPE) and OSH oversight were prohibitive for many smaller contractors to effectively complying with workplace safety policy. As a result of this cost predicament, many contractors retained a smaller worker compliment. Many sustained injuries, and experienced stress and burnout and these outcomes limited their capacity to work in the future.

\section{Questionnaire:}

As shown in Table 7 below, over eight five percent $(85.1 \%)$ of questionnaire respondents indicated that work accidents rarely occurred. However, over thirty-four percent $(34.4 \%)$ indicated that their work affected their health. Further, 28.5\% reported that they experienced intimidation or threats at work, and $19.9 \%$ received threats of job or salary loss for complaining about health and safety risks. Only $20.4 \%$ of employers provided means for stress relief. 
Table 7. Accidents and Illnesses, and Psychosocial Work Conditions

\begin{tabular}{|c|c|c|c|}
\hline \multirow{5}{*}{ Question 21} & \multirow{5}{*}{ Work accidents rarely occur? } & Strongly agree & $28.2 \%$ \\
\hline & & Agree & $56.9 \%$ \\
\hline & & Disagree & $8.3 \%$ \\
\hline & & Strongly disagree & $0.6 \%$ \\
\hline & & Undecided & $6.1 \%$ \\
\hline \multirow[t]{2}{*}{ Question 41} & \multirow{2}{*}{$\begin{array}{l}\text { During the past } 6 \text { years have you had accidents at } \\
\text { work? }\end{array}$} & Yes & $21.3 \%$ \\
\hline & & No & $78.7 \%$ \\
\hline \multirow[t]{3}{*}{ Question 38} & \multirow[t]{3}{*}{ Does your work affect your health? } & Yes & $34.4 \%$ \\
\hline & & No & $54.3 \%$ \\
\hline & & Don’t Know & $11.3 \%$ \\
\hline \multirow[t]{7}{*}{ Question 33} & $\begin{array}{l}\text { Which of the following issues take place at your } \\
\text { workplace? }\end{array}$ & Yes & No \\
\hline & Intimidation or threats & 28.5 & $71.5 \%$ \\
\hline & Physical violence from people from your workplace & 6.5 & $93.5 \%$ \\
\hline & Physical violence from other people & 5.9 & $94.1 \%$ \\
\hline & Sexual harassment or unwanted sexual attention & 9.1 & $90.9 \%$ \\
\hline & Discrimination linked to disability & 4.8 & $95.2 \%$ \\
\hline & $\begin{array}{l}\text { Threats of loss of job or salary for complaining about } \\
\text { health and safety risks }\end{array}$ & 19.9 & $80.1 \%$ \\
\hline \multirow[t]{2}{*}{ Question 40} & \multirow{2}{*}{$\begin{array}{l}\text { Does your employer provide you with means for relief } \\
\text { of work stress including any of the following: fitness } \\
\text { programmes, employee assistance programs, gym, } \\
\text { sporting clubs, wellness initiatives? }\end{array}$} & Yes & $20.4 \%$ \\
\hline & & No & $79.6 \%$ \\
\hline
\end{tabular}

\section{$\underline{\text { Correlational Analysis }}$}

A weak negative correlation was observed between "Policy" and "Health Issues": Pearson Correlation coefficient $-.150, \mathrm{p}=0.05$. This suggests that there tend to be increased reports of health issues at workplaces where policy requirements were being implemented. This is shown in Table 8 below. 
Table 8. Correlation Matrix

\begin{tabular}{|c|c|c|c|}
\hline & $\begin{array}{c}\text { Accident } \\
\text { Frequency }\end{array}$ & $\begin{array}{c}\text { Accidents Past } \\
\text { 6 Years }\end{array}$ & $\begin{array}{c}\text { Health } \\
\text { Impact }\end{array}$ \\
\hline Policy Index & $0.415^{* *}$ & -0.102 & $-.150^{*}$ \\
\hline
\end{tabular}

** Correlation is significant at the 0.01 level (2-tailed)

* Correlation is significant at the 0.05 level (2-tailed)

Manufacturing

Interview:

About $97 \%$ percent of the interview respondence indicated that they were less interested in health and safety and were generally more interested in their economic survival as they struggled to cope on minimum and low wages. The same group of respondents stated that their employers did not create positive working environments and were not interested in their welfare. As a consequence, they often tend to disregard safety rules and safety advice, focussing instead on attempts to earn more based on daily work output. As a result, on compliance of the OSH policy accidents frequently occurred.

Questionnaire:

Table 9 overleaf indicates that seventy-nine percent $(79 \%)$ of questionnaire respondents indicated that work accidents rarely occurred. However, 23.2\% reported that they had accidents over the past six (6) years. Approximately thirty-one percent (30.8\%) indicated that their work affected their health. Further, twenty-three percent $(23.8 \%)$ reported that they experienced intimidation or threats at work, and $10.1 \%$ received threats of job or salary loss for complaining about health and safety risks. Only $22.6 \%$ of employers provided means for stress relief.

Table 9. Accidents and Illnesses, and Psychosocial Work Conditions

\begin{tabular}{|l|l|c|c|}
\hline \multirow{2}{*}{ Question 21 } & \multirow{2}{*}{ Work accidents rarely occur? } & Strongly agree & $21.6 \%$ \\
\cline { 3 - 4 } & & Agree & $57.4 \%$ \\
\cline { 3 - 4 } & & Disagree & $11.5 \%$ \\
\cline { 3 - 4 } & & Strongly disagree & $3.1 \%$ \\
\cline { 3 - 4 } & & Undecided & $6.3 \%$ \\
\hline Question 41 & During the past 6 years have you had accidents at & Yes & $23.2 \%$ \\
\cline { 3 - 4 } & work? & No & $76.8 \%$ \\
\hline Question 38 & Does your work affect your health? & Yes & $30.8 \%$ \\
\hline
\end{tabular}




\begin{tabular}{|c|c|c|c|}
\hline & & No & $53.4 \%$ \\
\hline & & Don't Know & $15.9 \%$ \\
\hline \multirow[t]{7}{*}{ Question 33} & $\begin{array}{l}\text { Which of the following issues take place at your } \\
\text { workplace? }\end{array}$ & Yes & No \\
\hline & Intimidation or threats & 23.8 & $76.2 \%$ \\
\hline & Physical violence from people from your workplace & 4.6 & $95.4 \%$ \\
\hline & Physical violence from other people & 3.4 & $96.6 \%$ \\
\hline & Sexual harassment or unwanted sexual attention & 4.9 & $95.1 \%$ \\
\hline & Discrimination linked to disability & 6.1 & $93.9 \%$ \\
\hline & $\begin{array}{l}\text { Threats of loss of job or salary for complaining about } \\
\text { health and safety risks }\end{array}$ & 10.1 & $89.9 \%$ \\
\hline \multirow[t]{2}{*}{ Question 40} & \multirow{2}{*}{$\begin{array}{l}\text { Does your employer provide you with means for relief } \\
\text { of work stress including any of the following: fitness } \\
\text { programmes, employee assistance programs, gym, } \\
\text { sporting clubs, wellness initiatives? }\end{array}$} & Yes & $22.6 \%$ \\
\hline & & No & $77.4 \%$ \\
\hline
\end{tabular}

\section{Correlational Analysis}

As is shown in Table 10 overleaf, significant correlations were not observed.

Table 10. Correlation Matrix

\begin{tabular}{|c|c|c|c|}
\hline & $\begin{array}{c}\text { Accident } \\
\text { Frequency }\end{array}$ & $\begin{array}{c}\text { Accidents Past } \\
\text { 6 Years }\end{array}$ & $\begin{array}{c}\text { Health } \\
\text { Impact }\end{array}$ \\
\hline Policy Index & $0.315^{* *}$ & $-0.203^{* *}$ & $-.162^{* *}$ \\
\hline
\end{tabular}

** Correlation is significant at the 0.01 level (2-tailed)

* Correlation is significant at the 0.05 level (2-tailed)

Petrochemical Industry:

Interview:

Among the respondents interviewed $67 \%$ indicated that multinational companies provided illness prevention and other occupational medicine and wellness services for their staff. On the other hand, $33 \%$ of the respondents stated that contractors and local companies provided fewer comprehensive services. About $70 \%$ of respondents that have been working in the petrochemical industry long before the OSH policy was enacted in 2004 and amended 2006 stated that the national OSH policy brought about an overall increase in occupational health service provision. Notwithstanding, $30 \%$ of the interview respondents indicated that the 
national OSH policy did not influence petrochemical companies to investigate and disclose the aetiology of suspect occupational health fatalities.

Approximately $87 \%$ of the respondents indicated the OSH policy made their company to compel their staff to undertaking Job Safety Analyses (JSAs) and obtaining permits prior to starting work each day. This caused them to experience stress. These efforts made staff to be more safety conscious than was the case before the policy was enacted.

Questionnaire:

Table 11 below indicates that just over eighty-four percent $(84.1 \%)$ of questionnaire respondents indicated that work accidents rarely occurred. However, 14.5\%, i.e. 145/1000 reported that they had accidents over the past six (6) years. Thirty-nine percent $(39.7 \%)$ indicated that their work affected their health. Thirty-two percent, $(36.2 \%)$ reported that they experienced intimidation or threats at work, and $18.9 \%$ received threats of job or salary loss for complaining about health and safety risks. Approximately sixty-four percent $(63.7 \%)$ of employers provided means for stress relief.

Table 11. Accidents and Illnesses, and Psychosocial Work Conditions

\begin{tabular}{|c|c|c|c|}
\hline \multirow{5}{*}{ Question 21} & \multirow{5}{*}{ Work accidents rarely occur? } & Strongly agree & $26.3 \%$ \\
\hline & & Agree & $57.8 \%$ \\
\hline & & Disagree & $12.7 \%$ \\
\hline & & Strongly disagree & $2.2 \%$ \\
\hline & & Undecided & $1 \%$ \\
\hline \multirow[t]{2}{*}{ Question 41} & \multirow{2}{*}{$\begin{array}{l}\text { During the past } 6 \text { years have you had accidents at } \\
\text { work? }\end{array}$} & Yes & $14.5 \%$ \\
\hline & & No & $85.5 \%$ \\
\hline \multirow[t]{3}{*}{ Question 38} & \multirow[t]{3}{*}{ Does your work affect your health? } & Yes & $39.7 \%$ \\
\hline & & No & $43.5 \%$ \\
\hline & & Don’t Know & $16.7 \%$ \\
\hline \multirow[t]{5}{*}{ Question 33} & $\begin{array}{l}\text { Which of the following issues take place at your } \\
\text { workplace? }\end{array}$ & Yes & No \\
\hline & Intimidation or threats & 36.2 & $63.8 \%$ \\
\hline & Physical violence from people from your workplace & 4.1 & $95.9 \%$ \\
\hline & Physical violence from other people & 1.9 & $98.1 \%$ \\
\hline & Sexual harassment or unwanted sexual attention & 8.5 & $91.5 \%$ \\
\hline
\end{tabular}




\begin{tabular}{|l|l|c|c|}
\hline & Discrimination linked to disability & 5.7 & $94.3 \%$ \\
\cline { 2 - 4 } & $\begin{array}{l}\text { Threats of loss of job or salary for complaining about } \\
\text { health and safety risks }\end{array}$ & 18.9 & $81.1 \%$ \\
\hline Question 40 & $\begin{array}{l}\text { Does your employer provide you with means for relief } \\
\text { of work stress including any of the following: fitness } \\
\text { programmes, employee assistance programs, gym, } \\
\text { sporting clubs, wellness initiatives? }\end{array}$ & Yes & $63.7 \%$ \\
\hline
\end{tabular}

Correlational Analysis

Significant correlations were not observed. This is shown in Table 12 below.

Table 12. Correlation Matrix

\begin{tabular}{|c|c|c|c|}
\hline & $\begin{array}{c}\text { Accident } \\
\text { Frequency }\end{array}$ & $\begin{array}{c}\text { Accidents Past } \\
\text { 6 Years }\end{array}$ & $\begin{array}{c}\text { Health } \\
\text { Impact }\end{array}$ \\
\hline Policy Index & 0.502 & -0.205 & -.226 \\
\hline
\end{tabular}

** Correlation is significant at the 0.01 level (2-tailed)

* Correlation is significant at the 0.05 level (2-tailed)

Major Findings of Hypothesis 2

This section analyzes the Interview and Questionnaire data that are relevant to Hypothesis 2.

Hypothesis 2: There is a positive relationship between the OSH policy and workers' contribution to the sustainable development of Trinidad and Tobago:

\section{Construction Industry}

There was agreement among respondents that accident frequency, particularly the incidence of serious accidents decreased since the enactment of the OSH policy. Respondents also indicated that work stoppages due to refusal to work incidents also decreased. However, decrease in accidents was not as evident in smaller construction operations. These workers continued to experience injuries and high work demands, and smaller contractors found it challenging to afford the 'costs' of safety inputs.

Many questionnaire respondents reported work-related health issues, and almost thirty percent $(30 \%)$ reported intimidation and threats. The correlation analysis results supported this finding in that more health issues were reported as the number of health and safety committees increased. A positive relationship between the OSH policy and workers' contribution to workers safety and health was not identified. Hypothesis 2 is rejected

\section{Manufacturing Industry}

There was agreement amongst respondents that many employers did not attempt or did not make suitable and sufficient attempts to create positive working environments and to reduce 
accidents and other downgrading events. Accidents continued to occur within the sector also because both employers and employees prioritized economic motives over OSH compliance. Approximately thirty-one percent $(31 \%)$ of questionnaire respondents indicated that their work affected their health, and many worked under stressful conditions. The majority of employers did not provide means for stress relief. Significant correlations were not identified between the policy, and accidents and illnesses. A positive relationship between the OSH policy and workers' contribution to workers safety and health was not identified. Hypothesis 2 is rejected.

\section{$\underline{\text { Petrochemical Industry }}$}

Many respondents indicated that some companies undertook actions to comply with the policy and these resulted in less accidents and related down time. Notwithstanding, analysis of the questionnaire data did not reveal significant correlations between the policy and workers contribution to sustainable development. Approximately forty percent $(40 \%)$ of questionnaire respondents indicated that their work affected their health, and many worked under stressful conditions. However, the majority of employers provided means for stress relief. Over fourteen percent (14.5\%) of the respondents (i.e. 145/1000 workers) reported that they had accidents over the past six (6) years, and these accidents reduced productive output. Work stoppages often occurred because there were increased attempts by workers to abuse the "Refusal to Work" provision in the OSH policy. A positive relationship between the OSH policy and workers' contribution to workers safety and health was not identified. Hypothesis 2 is rejected.

\section{Policy Recommendations}

The result of the research found that there has been limited gains and few positive policy outcomes. This is because the OSH Agency does not pursue a coordinated policy implementation initiative. This shortcoming has contributed negatively to the underlying and persistent absence of employers' commitment to complying with the national OSH policy. In order to solve the present predicaments facing the OSH policy in Trinidad and Tobago, the government of the country should place the national OSH policy prominently on its policy evaluation agenda. Cognizant of this research's findings and mindful that ten (10) years have passed since the national OSH policy was enacted, it is timely and urgent that this be done. Strengthen governmental oversight mechanisms, or develop and implement new audit and accountability mechanisms to ensure that policy objectives are being aggressively pursued. The Government should also undertake a comprehensive and systematic independent evaluation of the OSH Agency's operations, management and implementation processes, and intervene as necessary to ensure that it can become maximally effective. Pursue a balanced approach to policy implementation that considers economic, social, cultural and technological realities, and that engages in compliance facilitation as well as application of prescribed legislative sanctions where warranted. It must also ensure that suitable and sufficient numbers of OSH Inspectors and relevant support staff are hired.

It is also recommended that the Government of Trinidad and Tobago should increase the budget of the OSH Agency to hired more qualified inspectors. This is because this research 
found that one of the reasons for the infective implementation of the OSH policy is due to lack of adequate qualified inspectors to monitor the safety and health activities in the three industrial sectors under study.

In addition, it is recommended that the government should prioritize the development of regulations, standards and codes. The OSH Authority and Agency should actively undertake or commission $\mathrm{OSH}$ research that can provide unambiguous cues to action. Research for example to include the identification of high risk groups, gaining understanding of economic obstacles to compliance, and identifying particular OSH challenges that non-permanent workers might be experiencing. The following sector-specific recommendations are also provided:

\section{Construction Sector:}

The OSH Agency should identify effective means to ensure that include adequate health and safety pricing considerations in construction bids. The agency should increase inspection oversight across the sector. Contractors should be encouraged to obtain Workmen's Compensation insurance coverage for all workers.

\section{Manufacturing Sector:}

The agency should ensure that employers comply with the policy's requirement to report accidents. The agency should actively advocate for employers to safeguard the welfare of injured workers.

\section{Petrochemical Sector:}

The OSH Agency should ensure that appropriate medical monitoring system is being undertaken. Contractors and sub-contractors should be mandated to comply with the Workmen's Compensation Act's requirement to provide health care and compensation to injured and ill workers. The OSH Agency and the Ministry of Energy should collaborate for avoidance of conflicting regulatory actions.

\section{Tobago:}

The Ministry of Labor should facilitate OSH Agency - THA discussions to remove obstacles to policy implementation in Tobago. The agency should encourage and assist the Tourism and Hospitality industry to map out an OSH policy compliance strategy. The agency should undertake educational activities to improve safety culture across the island.

Failure to safeguard workers safety and health undoubtedly will continue to negatively impact upon the nation's efficient production prospects unless there are more effective OSH policy implementation initiatives introduced. It is therefore imperative for the Government of Trinidad and Tobago to ensure that both large and small or multinational and domestic corporations are mandated to seriously pursue compliance or face fines and legal actions.

\section{Conclusions}

The paper has analyzed the effectiveness of the Trinidad and Tobago's occupational safety 
and health policy in the construction, manufacturing, and petrochemical industrial sectors 2006 - 2017. The paper shed light on how policy alone and the establishment of an OSH Authority and Agency were insufficient to protect workers. Additional mechanism to achieve future successful outcomes are strong government commitment, leadership, good governance, progressive vision regarding social protection, accountability, more qualified OSH inspectors, and strong collective representation.

The enactment of the policy in 2004 and amendment in 2006, more than ten (13) years ago did not succeed in bringing about safer and healthier work environments in Tobago, or within the construction, manufacturing, and petrochemical industrial sectors in Trinidad. There have been limited gains, few policy outputs and even fewer positive policy outcomes. It is clear that what needs to be done to protect workers and to stave off negative societal impacts cannot only be a technical 'policy implementation' discussion but must be a wider public policy education. It is timely now after a decade to reengage. It is prudent and urgent that a concerted effort at policy implementation be initiated, and that essential tools, resources, qualified inspectors, strategic direction and executive oversight be provided to ensure sustenance and success of this important change management process.

UNEP (2006), UNESCO (2005) and Mark-Davis and Mazuner (2003) argued that the majority of developing countries do not have adequate OSH policies and that this obtains because a series of mechanisms contribute to a lack of implementation. These scholars and institutions argued that the ineffectiveness of the OSH policies in developing countries is due mainly to lack of resources, underfunding, lack of political will, prevailing ideologies of economic neoliberalism and focus on economic growth. These factors have been reaffirmed in this Trinidad and Tobago research. It is therefore prudent that the Government of Trinidad and Tobago introduce a pragmatic policy evaluation to ensure that workers safety and health are protected everywhere in the country.

The lack of political support and absence of policy implementation oversight and accountability strongly suggested that there has been disregard for workers' fundamental right to a healthy and safe working environment. It also leans towards an inescapable conclusion that there has been deviation from the original policy intent to secure the safety, health and welfare of persons at work, and to protect others against safety or health risks in connection with the activities of persons at work. There was a negative relationship between OSH policy and workers' safety and health in Trinidad and Tobago.

Finally, future research should be conducted to gain a better understanding of the extent to which small, medium and micro enterprises are burdened to comply with the OSH policy. There is also the need to investigate of the social and economic impact of the national OSH policy in other industrial sectors in Trinidad and Tobago.

\section{References}

Allen, M., \& Dibie, R. (2016). The Impact of the occupational health and Safety and Health Policy in the Agriculture and Health Industries in Trinidad and Tobago. Journal of Applied and Theoretical Environmental Science, 2(2), 1-28. 
Ashford, N. (1976). Crisis in the Workplace: Occupational Disease and Injury. A report to the Ford Foundation. Cambridge, USA, MIT Press.

Benjamin, P., \& Greef, J. (1997). The report of the Committee of Inquiry into a National Health and Safety Council in South Africa. Johannesburg, Department of Labor.

Carneiro, F. G., Longmore, R., \& Riveira, M. (2014). Poverty Reduction and Economic Management Network: A future without Oil? Diversity Options for Trinidad and Tobago: Why Is Diversification Important for T\&T? www.worldbank.org/Economicpremise. Accessed September 12, 2019

Dahle, I. B., Wiig, S., Hebers, H., \& Lootz, E. (2010). Regulatory Approach to Improving Working Conditions for Groups Exposed to Risk within Norwegian Oil and Gas Industry." In proceedings Nordisk Ergonomic Conference, NES, Stavanger, G-8 September, Stavanger.

Dawson, S., et al. (1988). The limits of self-regulation, Cambridge University Press.

Dibie, R. (2013). Economic and Social Impact of Environmental Policy in Trinidad and Tobago. Journal of International Politics and Development, 11(1) \&2, 107-132.

Dibie, R. (2014). Comparative Perspective of Environmental Policies and Issues. New York, N.Y.: Routledge Press. https://doi.org/10.4324/9780203067819

Dryzek, J. S. (1997). The Politics of the Earth: Environmental Discourses, Oxford, University.

Dye, T. (2011). Understanding Public Policy. $13^{\text {th }}$ Edition. New York: Longman, pp. 210-231.

Friis, R. (2019). Occupational Health and Safety for the $21^{\text {st }}$ Century. Burlington, M.A.: Jones \& Barlett Learning.

Gibbs, D. (2000). Ecological modernization, regional economic development and regional development agencies, Geoforum, 31, 9-19. https://doi.org/10.1016/S0016-7185(99)00040-8

Gouldson, A., \& Murphy, J. (1997), 'Ecological modernization: restructuring industrial economies', in Jacobs, M. (ed.), Greening the Millennium? The New Politics of the Environment, 10, 12-23.

Government of Trinidad and Tobago. (2010). National EnvironmentalPolicy for Trinidad and Tobago. Government Press.

Government of Trinidad and Tobago. (2013). The National Oil Spill Contingency Plan. http://www.energy.gov.tt/wp-content/uploads/2013/11/62.pdf. Accessed August 20, 2019.

Government of Trinidad and Tobago. (2014). An overview of the oil and gas industry in Trinidad and Tobago. Ministry of Energy and Energy Affairs. http://caribbean.cepal.org/content/overview-oil-and-gas-industry-trinidad-and-tobago.

Accessed August 20, 2019.

Hajer, M. A. (1996). Ecological modernisation as cultural politics, in Lash, S. et al. (eds), 
Risk, Environment and Modernity Towards a New Ecology, London, Sage, pp. 246-268. https://doi.org/10.4135/9781446221983.n12

Hermanus A. M. (1999). Trend in Occupational Health and safety policy and regulations issues and challenges for South Africa. Takena Program in International Health: Harvard School of Public Health

Kelman, S. (1981). Regulating America, regulating Sweden: A comparative study of occupational safety and health policy. Cambridge, MA, MIT Press. https://doi.org/10.2307/1288225

Kraft, M. (2010). Environmental Policy and Politics. New York: Longman Press, pp. 11-23.

Kraft, M., \& Furlong, S. (2018). Public Policy: Politics, Analysis, and Alternatives. Washington D.C.: Congressional Press, pp. 322-337.

Kriebel, D., Tickner, J., \& Epstein, P. et al. (2001). The Precautionary Principle in Environmental Science, Environmental Health Perspectives, 109, 871-876. https://doi.org/10.1289/ehp.01109871

Lavicoli, S., Natali, E., Deitinger., P., Rondinone, B., Ertel, M., Jain, A., \& Leka, S. (2011). Occupational Health and safety Policy and Psychosocial Risks in Europe: The Role of $\begin{array}{lllll}\text { Stakeholders' } \quad \text { Perception. } & \text { Health } & \text { 8olicy, }\end{array}$ https://doi.org/10.1016/j.healthpol.2010.08.005

Levy, B., Wegman, D., Baron, S., Sokas, R. (2011). (Ed.) Occupational and Environmental Health. Six Edition. New York, NY: Oxford University Press.

Mark-Davies, J., \& Mazumder. (2003). Health and environmental policy issues in Canada: the role of watershed management in sustaining clean drinking water quality at surface $\begin{array}{llll}\text { sources. Journal of Environmental } & \text { Management68, 283-286. }\end{array}$ https://doi.org/10.1016/S0301-4797(03)00070-7

Maxwell, N. (2014). Understanding Environmental Health. Second Edition. Burlington, MA: Jones \& Bartlett Learning.

Meadowcroft, J. (1999). The Politics of Sustainable Development: Emergent Arenas and Challenges for Political Science. International Political Science Review, 20(2), 219-237. https://doi.org/10.1177/0192512199202006

Misiti, S., \& Bagnara, S. (1985). Participation in Health Control at the Workplace. Work and Health in the 1980's. Experiences of direct workers' partipation in occupational health. In S. Bagnara, R. Misiti and H. Wintersberger (1985). Berlin, Edition Sigma. Science Centre Berlin.

Mol, A. (2001). Globalization and Environmental Reform: The Ecological Modernization of the Global Economy. Cambridge, MA: The MIT Press, 48-56. https://www.esf.edu/es/sonnenfeld/ecomod_intro.htm. Accessed September 10, 2019

Moreau, D., \& Barbara, N. (2009). Occupational Health and Safety Hazards in Atlantic 
Canada Acquaculture: Laying the Groundwork for Prevention. Marine Policy, 33, 401-411. https://doi.org/10.1016/j.marpol.2008.09.001

Mulchansingh, C. V. (1971). The Oil Industry in the Economy of Trinidad. Caribbean Studies, 11(1)(April), 73-100.

Naschold, F. (1985). Dynamics without Structural Change. The Case for the Federal Republic of Germany. Work and Health in the 1980s. Experiences of direct workers' participation in occupational health. In S. Bagnara, R.Misiti and H. Wintersberger (1985). Berlin, Sigma Edition. Science Center Berlin.

Oscarsson, B. (1985). Swedish reforms on working environment- legislation, cooperation, research and training. Work and Health in the 1980s, Experiences of direct workers' participation in occupational healtn. In S. M. Bagnara, R and Wintersberger, H. (1985). Berlin, Edition Sigma, Science Center Berlin.

Samson, P. R. (2002). Developing Environmental Public Health Indicators: A view from Canada. Statistical Journal of the United Nations ECE 19, 105-116.

Sergeant, K., Racha, S., \& John, M. (2003). The Petroleum Sector: The Case of Trinidad and Tobago. Trends, Policies and Impact 1985-2000. http://citeseerx.ist.psu.edu/viewdoc/download?doi=10.1.1.530.5156\&rep =rep1\&type =pdf. Accessed August 17, 2018

Spoolman, S., \& Tyler, G. M. G. (2012). Environmental Science. Pacific Grove, CA: Brook/Cole.

Suarez, R., \& Elias, C. (ed). (2006). From Growth to Prosperity: Policy Perspective for Trinidad and Tobago. Washington D.C.: Inter-American Development.

Taylor, R. (2012). Taking Sides: Clashing Views in Sustainability. New York: McGraw-Hill Press.

Tyler, M., \& Spoolman, S. (2012). Living in the Environment. Belmont, CA: Brooks and Cole, pp. 31-54.

United Nations Educational, Scientific and Cultural Organization (UNESCO), The Precautionary Principles, (2005). Available at www.unesco.org/images/0013/ 139578e. Accessed August 19, 2019

United Nations Environmental Programme (UNEP). (2006). New Report Underlines Africa's Vulnerability to Climate Change. Nairobi, 5 November. Retrieved from http://new. unep.org /Documents. Multilingual/ Default .asp?DocumentID=485\&ArticleID=5409\&l=en. Accessed August 17, 2019.

Waller-Hunter, J., \& Jones, T. (2002). Globalization and Sustainable Development. International Review for Environmental Strategies, 3(1), 53-62.

Willis, R. (1985). The role of the Commonwealth. The Industrial Relations of Occupational Health and Safety. B. Creighton and N. Gunningham . Sydney, Australia, Croom Helm 
Australia.

Withgott, J., \& Brennan, S. (2008). Environment; The Science Behind the Stories. San Francisco, CA: Pearson Books, p. 20-27.

Woods, N., \& Potoski, M. (2010). Environmental Federalism Revisited: Second-Order Devolution in Air Quality Regulation. Review of Policy Research, 27(6), 721-727. https://doi.org/10.1111/j.1541-1338.2010.00468.x

World Bank Group. (2019). The World Bank in the Caribbean. https://www.worldbank.org/en/country/caribbean /overview. Accessed August 19, 2019.

World Health Organization Report. (1999). Environmental Health Indicators: Framework and Methodologies. Geneva, Switzerland: WHO Technical Report Series, WHO/SDE/OEH/99.10.

World Health Organization Report. (1999). Global Burden of Injuries. Geneva: WHO Technical Report Series 11-25.

World Health Organization Report. (2002). Quantifying Selected Risks to Health: Reducing Risks Promoting healthy Life. WHO Technical Report Series, 73-78.

Wright, T. S. A. (2002). Definitions and Frameworks for Environmental Sustainability in Higher Education. International Journal of Sustainability in Higher Education, 3(3), 203-220. https://doi.org/10.1108/14676370210434679

\section{Copyright Disclaimer}

Copyright for this article is retained by the author(s), with first publication rights granted to the journal.

This is an open-access article distributed under the terms and conditions of the Creative Commons Attribution license (http://creativecommons.org/licenses/by/4.0/). 